E3S Web of Conferences 1, 13007 (2013)

DOI: $10.1051 / \mathrm{e} 3$ sconf/20130113007

(c) Owned by the authors, published by EDP Sciences, 2013

\title{
Uptake of uranium by native aquatic plants: potential for bioindication and phytoremediation
}

\author{
$\underline{\text { P. J. C. Favas }}^{1,3}$ and J. Pratas ${ }^{2,3}$ \\ ${ }^{1}$ Department of Geology, University of Trás-os-Montes e Alto Douro, Vila Real, PORTUGAL, pjcf@utad.pt \\ ${ }^{2}$ Department of Earth Sciences, University of Coimbra, Coimbra, PORTUGAL \\ ${ }^{3}$ IMAR-CMA Marine and Environmental Research Centre, University of Coimbra, Coimbra, PORTUGAL
}

\begin{abstract}
The work presented here is a part the on going study on the uraniferous geochemical province of Central Portugal in which, the use of aquatic plants as indicators of uranium contamination is being probed using aquatic plants emphasizing their potential use in the emerging phytotechnologies. Even though we have observed very low concentration of $U$ in the fresh waters of the studied sites we found a set of vegetable species with the ability to accumulate $U$ in concentrations which are orders of magnitude higher than the surrounding environment. We have observed that Apium nodiflorum, Callitriche stagnalis, Lemna minor and Fontinalis antipyretica accumulated significant amounts of uranium, whereas Oenanthe crocata excluded U. These results indicate substantial scope for proper radiophytoremediation and phytosociological investigation exploiting the native flora. These species show great potential for phytoremediation because they are endemic and easy to grow in their native conditions. A. nodiflorum and C. stagnalis have high bioproductivity and yield good biomass.
\end{abstract}

Key words: Aquatic macrophytes, bioaccumulation, biomonitoring, native flora, phytofiltration

\section{Introduction}

Plants capable of growing on trace element contaminated sites, abandoned mine sites usually indicate the mineral composition of the soil and waters. These plant species are able to accumulate or exclude toxic metals and hence, tolerant to the imposed stress. This function is of considerable significance in the emerging areas of phytotechnologies (Prasad, 2004). This communication is a part the on going study on the uraniferous geochemical province of Central Portugal in which, the use of aquatic plants as indicators of uranium contamination is being probed using aquatic plants emphasizing their potential use in the emerging phytotechnologies.

In the present study we analyzed the aquatic community and identified potential species for phytotechnological application to immobilize $U$ on a longterm basis for ecological restoration of the comtaminated sites.

\section{Materials and Methods}

The samples for this work were collected in running and in standing waters (lentic and lotic) in the places were it was possible to observe aquatic species. In these sites, samples of the waters and of the vegetable species were taken. The plants collected represented the free floating and the rooted emergent plants. In the ponds, only free floating plants were found growing. Plants used in this investigation have been identified with the help of local flora and herbarium of the Department of Life Sciences, University of Coimbra, Portugal.

All samples were processed in the Chemistry Laboratory of the Earth Science Department of University of Coimbra. The waters were filtered and acidified. The plants were cleaned in running water in order to clean the surface bound particles, and were dried in an oven at $60{ }^{\circ} \mathrm{C}$. The dried plant samples were ground to homogenous powder for further analysis.

For determination of the mass concentration of $U$ in samples of natural water and plants it was used the "Fluorat-02-2M" analyzer (made by Lumex, Russia). In this device the concentration of uranium in solution is deducted from the measurement of the intensity of the delayed fluorescence of the uranyl-ions $(\lambda=530 \mathrm{~nm})$. The water samples were analysed by standard fluorimetric analysis. For the control of the results it has been used a certified reference water produced by the National Water 
Table 1. Uranium in different plant species $(\mathrm{mg} / \mathrm{kg} \mathrm{DW})$ and in fresh waters $(\mathrm{ng} / \mathrm{mL})$.

\begin{tabular}{|c|c|c|c|c|c|}
\hline Plant & $\mathrm{n}$ & Min & Max & Background & $\mathrm{T} / \mathrm{t}$ \\
\hline Apium nodiflorum & \multirow{2}{*}{10} & 0.20 & 31.6 & \multirow[t]{2}{*}{0.31} & \multirow[t]{2}{*}{102} \\
\hline Waters & & 0.5 & 18.6 & & \\
\hline Callitriche stagnalis & \multirow{2}{*}{19} & 0.53 & 112.2 & \multirow[t]{2}{*}{0.66} & \multirow[t]{2}{*}{170} \\
\hline Waters & & 0.4 & 18.6 & & \\
\hline Lemna minor & \multirow{2}{*}{22} & 0.28 & 52.9 & \multirow[t]{2}{*}{0.43} & \multirow[t]{2}{*}{123} \\
\hline Waters & & 0.5 & 18.6 & & \\
\hline Oenanthe crocata & \multirow{2}{*}{10} & 0.03 & 1.7 & \multirow[t]{2}{*}{0.12} & \multirow[t]{2}{*}{14} \\
\hline Waters & & 0.4 & 18.6 & & \\
\hline Fontinalis antipyretica & \multirow{2}{*}{10} & 3.37 & 32.8 & \multirow[t]{2}{*}{3.83} & \multirow[t]{2}{*}{9} \\
\hline Waters & & 0.4 & 18.6 & & \\
\hline
\end{tabular}

$\mathrm{T} / \mathrm{t}$ - relation between the maximum and background level.

Table 2. Uranium in Lemna minor (mg/kg DW) and in standing and running waters (ng/mL).

\begin{tabular}{lcccccc}
\hline & $\mathrm{n}$ & $\mathrm{Min}$ & $\mathrm{Max}$ & Background & $\mathrm{T} / \mathrm{t}$ & $\mathrm{BAC}$ \\
\hline Plant concentration in running waters & & 0.41 & 8.54 & 0.40 & 21 & $1.56 \times 10^{3}$ \\
Waters & 8 & 0.5 & 18.6 & & & 118 \\
Plant concentration in standing waters & & 0.28 & 52.98 & 0.45 & $2.87 \times 10^{3}$ \\
Waters & 14 & 0.6 & 4.16 & & \\
\hline
\end{tabular}

BAC - Biological Absorption Coefficient

Research Institute of Canada (reference TMDA-62). The methodology adopted for the determination of the uranium content in the plants was fluorometry (Huffman \& Riley, 1970; Van Loon \& Barefoot, 1989). Certified Virginia tobacco leaves reference CTA-VTL-2 have also been analysed to validate the experimental procedure.

\section{Results and Discussion}

Even though we have observed very low concentration of $\mathrm{U}$ in the fresh waters of the studied sites we found a set of vegetable species with the ability to accumulate uranium in concentrations which are orders of magnitude higher than the surrounding environment. We have also seen one species that was inhibiting the uptake of this metal. For this preliminary work, we have selected Apium nodiflorum (L.) Lag., Callitriche stagnalis Scop., Lemna minor L., Fontinalis antipyretica L. and Oenanthe crocata L. among all the collected species because they were the most representative species. A summary of the chemical analysis results is presented in Table 1 .

The results show a strong accumulation of uranium in the plants in comparison to the uranium present in the water. From these observations, we conclude the chosen plants such as Callitriche stagnalis and Apium nodiflorum appear to be keystone species for further phytoremediation research to remove $U$ from mining effluents or in the phytoremdiation of $U$ contaminated sites. Apium nodiflorum allows a good rooting in all kinds of running and standing waters and the other three species are found to be appropriate for standing waters. Their biomass and bio-productivity are relatively high; serve as Apium nodiflorum and Callitriche stagnalis excellent indicators of $U$ pollution, since they showed a positive correlation with the $U$ present in the waters (Pratas et al., 2012).

Oenanthe crocata, in spite of its high biomass and bio-productivity, in its aerial organs does not reflect a significant accumulation and the values are not correlated with the $U$ found in the waters.

The bryophyte Fontinalis antipyretica which grows normally on top of the rocks within the waters reveals a strong ability to monitor the contamination present in the running waters.

The free floating Lemna minor shows good ability to accumulate uranium in a similar way as it has been observed in Lemna gibba (Mkandawire \& Dudel, 2005). However, it was observed a discrepancy when the results from running waters were compared with those from standing waters (Table 2).

Table 2 shows that the values of the maximum accumulation, the ratio $\mathrm{T} / \mathrm{t}$ and the Biological Accumulation Coefficient are much higher in the standing waters compared with those of the running waters. This indicates a positive correlation between concentration in the plant and the residence time for this accumulation. If this is proved to be the case then there is a good opportunity for its use in phytoremediation in closed tanks where it would be grown. This obviously depends on further studies regarding its biomass and bio-productivity. 
The species Fontinalis antipyretica proved to be a good candidate for biomonitoring. This species accumulates large quantities of $U$ in its tissues. It is known that, in general, the bryophytes have a great potential for rapid accumulation and exhibit seasonal fluctuations depending upon the environmental contaminants (Cenci, 2000). Also and due to the fact that this species does not have a root system, but the uptake occurs through the rhizoids as an ionic exchange between the environment and the basal portion of the plant. The biological accumulation coefficient for this species is high, of the order of $1.4 \times 10^{4}$, and this means it can be considered a hyperaccumulator plant following the definition of Brooks (1998).

L. minor, a floating plant and its $\mathrm{U}$ accumulation is related with the surrounding water concentration. It showed an average biological accumulation coefficient of $1.56 \times 10^{3}$ in running waters and of $2.87 \times 10^{3}$ in standing waters. Thus it has great potential for $U$ accumulation in running and standing waters, and can also be considered a potential accumulator of $U$.

\section{Conclusion}

This work focuses on $U$ contaminated waters (running and standing) and use of native plants for phytotechnology. The study area represented old uranium mines of Central Portugal and the present investigation indicates substantial scope for proper radiophytoremediation and phytosociological investigation exploiting the native flora. These species show great potential for phytoremediation because they are endemic and easy to grow in their native conditions.
A. nodiflorum and C. stagnalis have high bioproductivity and yield good biomass.

\section{References}

Brooks RR. Plants that Hyperaccumulate Heavy Metals, CAB International, 1998.

Cenci RM. The use of aquatic moss (Fontinalis antipyretica) as monitor of contamination in standing and running waters: limits and advantages. J Limnol 2000; 60:53-61.

Huffman, Jr. C., Riley, L.B., The Fluorimetric method its use and precision for determination of uranium in the ash of plants, U.S. Geol. Survey Prof. Paper, 700-B, 1970, pp. 181-183.

Mkandawire M, Dudel EG. Accumulation of arsenic in Lemna gibba L. (duckweed) in tailing waters of two abandoned uranium mining sites in Saxony, Germany. Science of the Total Environment 2005; 336:81-89.

Pettersson HBL, Johnston HA, Murray AS. Uptake of uranium and thorium series radionuclides by the waterlily, Nymphaea violacea, $J$ of Envir Radioactivity 1993; 19:85-108.

Prasad MNV. Heavy metal stress in plants: from biomolecules to ecosystems, Springer, 2004.

Pratas J, Favas PJC, Paulo C, Rodrigues N, Prasad MNV. Uranium accumulation by aquatic plants from uranium-contaminated water in Central Portugal. International Journal of Phytoremediation 2012; 14:221-234.

Van Loon JC, Barefoot RR. Analytical Methods for Geochemical Exploration, Academic Press, 1989. 